\title{
Classicism vs. Modernism in the Plays of T.S. Eliot: A Rare but Effective Art of Dramatization
}

\author{
Rimah Saleh Alyahya \\ Princess Nora University, Alnarjas District, Riyadh, Saudi Arabia
}

ABSTRACT

T.S. Eliot is an exceptional, unusual playwright. He fuses classicism and modernism in his plays and other literary works. However, this rare technique of making plays has been successfully used by him. He combines Greek myth and Christian rituals with contemporary issues, especially those relating to the masses or average citizens, in order to express his cultural ideals. Because of this special technique that is effectively wielded only by a few playwrights, T.S. Eliot included, he became an enigma for many literary historians. This paper thoroughly analyzes how T.S. Eliot uses both classicism and modernism in his plays, which is a rare but effective art of dramatization.

\section{KEYWORDS}

Classicism; modernism; transformation; conflict; dramatization; portrayal

\section{ACADEMIC DISCIPLINES AND SUB-DISCIPLINES}

Humanities studies

\section{SUBJECT CLASSIFICATION}

Library of Congress Classification

\section{TYPE (METHOD/APPROACH)}

The approach used in this research is literary criticism.

\section{Council for Innovative Research}

Peer Review Research Publishing System

Journal of Social Science Research

Vol.4, No.1

editor@jssronline.com

www.cirworld.com, www.jssronline.com 


\section{INTRODUCTION}

T.S. Eliot's critical plays establish the artistic norms for the New Criticism, and his newsletter Criterion was part of the main mediators of preference all over the 1920s and 1930s. The broad but somewhat little body of creations of Eliot-the sophisticated The Love Song of J. Alfred Prufrock, the pivotal The Waste Land, and the recent Four Quartets, which he regarded his magnum opus, has made him the leading icon of modernist plays both for his contemporaries and for later generations. The key to appreciating and making sense of Eliot's works requires understanding the core inconsistency that the "greatest literary Modernist should also be our greatest modern conservative" (Vanheste 5). It is perhaps this contradiction that has led to Eliot living in the popular imagination as a modernist primarily and classicist subsequently, or at times without the classicist side in the least. However, the two are inseparably tied.

Eliot observed a general strand of hypocrisy and self-absorption characterizing Romanticism, individualism, utilitarianism, humanism, and liberalism. Structure was vital to his standards, and this implied classicism, shared tradition, and convention against the domination of the Romantic self (Vanheste 5-6). He clearly described his perspective as a three-fold connection: "classicist in literature, royalist in politics, and Anglo-catholic in religion" (Dwivedi 70). He discarded completely the rigid pleasantness and romanticism of an exhausted, traditional Romanticism for a disjointed free-verse, typified by striking, urban symbolism, deterioration, severe, psychological distress. The Love Song of J. Alfred Prufrock is a theatrical portrayal of the decay of the Romantic self amid a foul modernity. The Waste Land accomplishes an accent from such temporal ineffectiveness to an image of ancient, eternal knowledge (Dwivedi 70-71). The deafening Sanskrit quotes in the play's Eastern pinnacle relate the refreshing rain of a fertility ceremony to the linguistic origin of the Indo-European language, and artistically operates as a way of revealing the rift of detachment between a worldly modernity and the value of convention (Bloom 215 ):

Ganga was sunken, and the limp leaves/ Waited for rain, while the black clouds/ Gather far distant, over Himayant/ The jungle crouched, humped in silence/ Then spoke the thunder [...]/ DattaDayadhyamDamyata/ Shantihshantihshantih.

Underneath the chaotic characteristic of modernity, Eliot tried to revive the antique fertility ceremonies of sacred rule and raise that to his modernist imagination. For the conservative modernist such as Eliot, myth conveyed in powerful language, provided a way of structuring and consolidating a fragmenting culture. With an appreciation of Nietzsche's notion of "the eternal return," mythology became "a means by which to adumbrate his vision of an ideal cultural order: permanent, organically unified, transcending history" (Eastham 48). This paper discusses how T.S. Eliot uses both classicism and modernism in his plays, which is a rare but effective art of dramatization.

\section{THE HARMONY BETWEEN CLASSICISM AND MODERNISM}

Thomas Stearns Eliot, or more widely known as T.S. Eliot, was born in 1888 and exposed to a traditional system of dogmatic principles rooted in classical frameworks that appeared to substantiate humanity's spiritual and social progress. Indeed, during his childhood and adolescence years, classicism was the main academic focus in humanities (Sarker 32). Verifying the connection between classicism, history, and evolution were remarkable scholars such as Samuel Butler and John Addington Symonds. Western history and literature created the basis for Eliot's plays. Eliot proclaimed himself a classicist (Sarker 32-33). The conflict between romanticism and classicism was originally identified by the German scholar and poet Karl Wilhelm Friedrich von Schlegel. He described classicism "as an attempt to express infinite ideas and feelings in a finite form and romanticism as an attempt to express a kind of universal poetry in the creation of which the poet made his own laws" (Sarker 33).

Goethe stated that romanticism is illness and classicism is vigor. Cuddon claims: "In general when we speak of classicism we refer to the styles, rules, modes, conventions, themes and sensibilities of the Classical authors, and, by extension, their influence on and presence in the work of later authors" (Sarker 33). Generally, classicism is more intellectual, still, proper, and social compared to romanticism. Classicism gives greater emphasis on aspects widespread among all people. Hence, it is still and social, for what is widespread among the majority seldom evolves. Classicism requires conformity, reflection, order, and restraint. Emotion is present in classicism, but it is deliberately measured. With regard to the proper regulation of emotion, Eliot argues that emotion could be present in plays but it 
should not exceed the standard (In order to be a classicist, one should also be a traditionist (Maddrey 66). Eliot was aware of this and, thus, proclaimed himself to be a traditionist and classicist.

While the presentation of a Greek drama was essentially a special religious activity and the Greek dramatists shared a sense of awareness with the viewers, a playwright in who tries to express or convey religious aspects in the theatre is burdened with the challenging duty of offering and performing an entire set of experience in a system of meaning. Eliot has assumed the duty of creating this system in the formal, procedural form of his plays, with the assistance of poetry-through its method of transforming reality (Das 111-12). Because Eliot consistently creates plays with a purpose of entertaining the viewers, he sustains a feature of truth in his plays in the temporal side of his plots, whereas a poetic contradiction creates the spatial feature or the religious aspect of his plays. However, the concept of the double pattern of reality as spoken in Eliot's plays can be attributed to the notion of fate's role as seen in classical plays. Eliot's description of this double pattern somewhat clarifies this problem (Das 112):

We perceive a pattern behind the pattern into which the characters deliberately involve themselves; the kind of pattern which we perceive in our own lives only at rare moments of inattention and detachment, drowsing in sunlight. It is the pattern drawn by what the ancient world called fate; stabilized by Christianity into mazes of delicate theology; and reduced again by the modern world into crudities of psychological or economic necessity.

Because the declared intention of Eliot, in almost all of his plays, is to transform the usual reality through a working poetic expression and dialogue, the system of his plays reminds audiences of the complicated transfigurations of Euripides' plays, through dramatic transformation of traditional reality (Tiwari 104). Here, the method of transformation as espoused by Euripides and Eliot includes, somehow, the dramatization of contradictions in a specific culture. This unavoidably places considerable pressure on Eliot's characters and frequently gives them a look of squeamishness or irrationality. Yet Eliot's technique of transformation varies clearly from Euripides' technique, because a dimension of grander or bigger reality becomes embodied in the worldly features of his plays only under the emphasis of poetry (Das 113).

The complicated issue of communication, which Eliot has creatively talked about in his plays, has encouraged him to accept Greek myths as external foundation of his drama. These Greek myths offer a body of human experience which the viewers can embrace as the parallel of an arrangement of action or as reality's mystical models. They create the context in which the playwright can develop or identify a system of meaning (Das 112-13). Moreover, besides the formalist values which Eliot adopts from the Greeks, his emphasis on the Christian belief of suffering or sacrifice as a solution to the current problem of faith endows his plays with a feeling of harmonizing simplicity as observed in classical drama. A classic example of classicism in Eliot's plays is The Family Reunion. The Family Reunion is a play about immorality and penance (Tiwari 106). Eliot mirrors here the meaninglessness, ridiculousness of life and plays up the fight of a repentant to transcend the border of the wicked world of doubt and go into the light of his/her soul's vision (Tiwari 106). Although Murder in the Cathedral portrays a saint's spiritual pursuit and existence, The Family Reunion depicts the spiritual reawakening of a common individual.

Eliot shows himself as a supporter of classicism in ways both shallow and insightful. This play closely discerns the harmonies of place and time. The usual subjects of ancient drama, sin and penance, are applied. Phantoms and a chorus conform to classical standards in plays. Both as a philosopher and a playwright, Eliot is intimate with classical drama. Eliot in The Family Reunion has attempted to portray the drama of contemporary life within the context of ritual. The dual components of Christian and Greek rituals are buried in the play's structure (Tiwari 107). Nevertheless, Christian sacrament of $\sin$ and salvation creates the framework of the play. Eliot makes use of the Greek parable of the Oresteia as the foundation of its plot and arranges it as "a crypto Christian play, with unfamiliar spiritual symbols and pagan overtones" (Tiwari 107). In The Family Reunion Eliot has reconciled the dual components of Christian and Greek rituals under the shade of the Greek mythology.

In The Elder Statesman, Eliot's last play, he combined modern dialogue, contexts, scenes, and plots with classical references and styles with the expectation that his intellectual audience would finally award tragic splendor and philosophical breadth to his noble public-man protagonist, developed and smoothed by experience (Murphy 159-60). The demise of the prosperous, effective statesman was heartbreaking enough, but the drama created cognitive and aesthetic walls that hindered one's perception of the nature of bravery or spiritual success of Lord Claverton. In The Elder Statesman, The Confidential Clerk, and The Family Reunion Eliot portrays the torment of the hero's soul before his spiritual appointment, with an intention of exposing the fear of an unfaithful generation (Murphy 160). 
After having relished for numerous years a leading role in many renditions of the narrative of $20^{\text {th }}$-century culture, Eliot has become somewhat a difficult subject for the literary scholar. The more thoroughly his life and works are examined today, the more ambiguous it is where his value or significance resides. Part of the dilemma is that now that the own "practice" of Eliot has come to appear unnatural or contrived, it is difficult to determine to what cultural lineage he could indeed possibly be stated to belong. He had a difficult affair, not entirely hostile, with the $19^{\text {th }}$-century cultural principles; yet he had a difficult affair, not entirely compassionate, with most of the principles of $20^{\text {th }}$-century modernism (Maddrey 49). It is frequently difficult to determine which path he is referring to; he appears in some instances to be the preserver of a specific tradition of literary standards and in other instances to be the expert of their disappearance-an inconsistency aggravated by his practice of depicting himself in his plays as the casualty of history and afterward recommending his own remedy in his analysis.

Eliot is strongly tied to global modernism. He was its most expressive supporter in his early analysis. His thoughts and his works demonstrate in abundant accuracy the drapery of modernism. His knowledge of history originates directly from scholars such as Pater, Nietzsche, and Marx; and because it is a rendition of an opinion widely held in common, it is very informative. Eliot's idea of tradition and European thought, once more adopted from the latter part of the $19^{\text {th }}$ century but adjusted to show his opinion of the early $20^{\text {th }}$ century, is crucial in understanding Joyce, Valery, Yeats, and other contemporary writers (Maddrey 49-53). The intellectual breadth of Eliot, particularly his criticism of fusion and his assertion of a sense of harmony, demonstrates an early structure in modernist thought.

Ultimately, the pattern of his thoughts, including surrender, mastery, and transcendence in sequence, describes the mental clash of a number of his most talented contemporary thinkers. This trend, a transmutation of Marxist and Hegelian conflict, includes an interaction between contradictions that progresses by returning and transcending (Haldar 84). It rises above Hegel, though, in opposing linearity, avoiding synthesis and shunning mentalism (Vanheste 27). This conflict, prevalent in the majority of modernist creations, emerges with particular precision in Eliot, intellectually the most learned of the modernists.

The new strand of plays that surfaced from Eliot's writing must weaken the detractors' resolution to criticize his plays, such as The Rock,as shallow propaganda. The quality is direct or instant, very modern; his plays avoid dominant modernism, Perkins argues: "The esotericism, phrasal density, formal complexity, and avant-garde experimentalism of high Modernism had less appeal, for they made poetry difficult and thus relegated it to a small number of readers... Poets wished to address issues in a language appropriate to intellectual discussion, and hence they used discursive or generalizing language" (Chinitz 433-34). The major starting point or theme for Eliot was, obviously, the realities of the outside world, and these were realities within which there was remarkable consensus: they "inhabited more or less the same imaginative world" (Chinitz 434). Perkins adds, significantly influenced by "the newspapers. By 'newspapers' I mean what was news in the 1930s-unemployment, depression, Communism, Fascism, spies, street mobs, dictators, treaties, arms races, wars-and also the fears, hopes, and strivings with which English intellectuals responded to these events" (Cuddy 246).

The response of the 1930s against the previous modernist art contained "a feeling of reaching out to an audience from isolation and to subject matter and life from form and art..." (Murphy 313)The quality "was conversational" (Murphy 313). It is not frequently emphasized that Eliot's Choruses-aside from being exceptional plays based on broad principles of tone and design that Eliot sustained-are exceptional in a manner that is not like the other exceptional plays of Eliot. They are dreary, modest, devoid of the severe trivial exclusiveness of Eliot's previous plays (Murphy 313-14). The Choruses are not precisely in the style of the subsequent developed design that characterizes Eliot's post-transformation plays, which is a transfiguration of previous plays into a more modest and more polite but equally exclusive and spectacular expression. There are merely several other instances of this kind of plays from the Choruses in other norms of Eliot. Journey of the Magi portrays the journey through the desert (Sarker 121):

... the camel men cursing and grumbling/ And running away, and wanting their liquor and women/ And the night-fires going out, and the lack of shelters/ And the cities hostile and the towns unfriendly/ And the villages dirty and charging high prices: A hard time we had of it.

This form successfully reorders, or espouses, an act from scriptural Israel to one of modest modern proximity, perfectly unhindered in this reordering by the inconsistency of 'camel men' (Sarker 121). Eliot fills the play with a direct natural quality; it is unremarkable, but adequate in aspect and hence persuasive.

In The Cultivation of Christmas Trees, "There are several attitudes towards Christmas/ Some of which we may disregard: The social, the torpid, the patently commercial/ The rowdy (the pubs being open till midnight)" (Murphy 
501). The impact of the imageries in lines such as these-their distinctive quality, their appearance of real everyday experiences unblemished by the pretense of fake modesty-stems from the incorporation into Eliot's plays of the plain, common, ever-present existence of the masses or the ordinary people, not with the political and social significance of the Soviet or Orwellian working class merely showing an understanding and recognition of the ordinary life, the shared experiences, of the European people in the miserable and subdued 1930s (Murphy 501). These images are somewhat hidden all over Eliot's plays, and they seem most obviously in his creations like The Rock. However, those that do emerge somewhere else are potent-for instance, the subversive acts of Four Quarters (Kramer 150): "the 'place of disaffection' in 'Burnt Norton' and the train passengers with their 'fruit, periodicals and business letters' as they depart from the platform in 'The Dry Salvages'; and the darkly banal venues of bleak modernism in Four Quartets such as the hollow theater in 'East Coker."'

In such lines from Eliot's plays, the position, the mood, and the language of these passages create new ground. In Ash Wednesday Eliot's claim "I rejoice that things are as they are" (Batra 93) may work as a maxim to his play of this time and to his whole playwright vocation-it shows the recognition of social realities that dominate all his plays inspired by modernism. This recognition symbolizes a vital phase in Eliot's evolution from 'poetic solipsism' to theatrical plays. Eliot is creating and introducing a new language. He is creating plays outside self-absorption or introspection and toward more broadly understandable and relevant social plays. Eliot's endeavors into modernism are also technical, rhythmical and expressive practices and an immense artistic transformation (Batra 93-94). The audience is aware of Eliot's evolution as it happens. In his previous plays, he attempted to push his audience to view the world through his eccentric perspective, his indifferent, skeptical, exclusive emotions.

Hence, for instance, in Mr. Apollinax, a recollection of a traditional Harvard gathering with Bertrand Russell turns out to be disturbingly and strangely distorted, totally and abnormally depicted (Haldar 33):

His laughter tinkled among the teacups.../ He laughed like an irresponsible foetus/ His laugher was submarine and profound/ Like the old man of the sea's/ Hidden under coral islands/ Where worried bodies of drowned men drift down in the green silence/ Dropping from fingers of surf.

However under the influence of this modern imagery, instead of enforcing his point of view on his reader, Eliot attempts to view things as other people do. In The Rock, this artistry is slightly influenced by Eliot's old-fashioned modernism, the mood of The Waste Land (Haldar 34); there are several occurrences of such rhythm and expression in the play, and somewhat, Eliot's modernism stems from this.

\section{CONCLUSION}

T.S. Eliot has mastered the art of dramatization through effectively contrasting classicism and modernism in his plays. He uses Greek myths and Christian rituals as a way of valuing tradition, but at the same time celebrates modernity by catering to the masses. For numerous readers, the plays of Eliot are simply and largely modernist. All aspects of his plays indicate grand modernism and classicism - their reference to myth to symbolize and structure individualized modern life; its fusion of various expressions, dialogues, and traditions; and its emphasis on form and style as the bearer of meaning.

\section{References}

[1] Batra, Shakti. T.S. Eliot. New Delhi: Sarup\& Sons, 2011. Print.

[2] Bloom, Harold. T.S. Eliot's The Waste Land. New York: Infobase Publishing, 2007. Print.

[3] Chinitz, David. A Companion to T.S. Eliot. New York: Wiley, 2011. Print.

[4] Cuddy, Lois. T.S. Eliot and the Poetics of Evolution: Sub/versions of Classicism, Culture, and Progress. London: Bucknell University Press, 2000. Print.

[5] Das, Jolly. Eliot's Prismatic Plays: A Multifaceted Quest. New Delhi: Atlantic Publishers \& Dist., 2007. Print. 
[6] Dwivedi, Amar. T.S. Eliot: A Critical Study. New Delhi: Atlantic Publishers \& Dist., 2002. Print.

[7] Eastham, Andrew. Aesthetic Afterlives: Irony, Literary Modernity and the Ends of Beauty. UK: Continuum International Publishing, 2011. Print.

[8] Haldar, Santwana. T.S. Eliot: A Twenty-First Century View. New Delhi: Atlantic Publishers \& Dist., 2005. Print.

[9] Kramer, Kenneth. Redeeming Time: T.S. Eliot's Four Quartets. Lanham, MD: Cowley Publications, 2007. Print.

[10] Maddrey, Joseph. The Making of T.S. Eliot: A Study of the Literary Influences. North Carolina: McFarland, 2009. Print.

[11] Murphy, Russell. Critical Companion to T.S. Eliot: A Literary Reference to His Life and Work. New York: Infobase Publishing, 2007. Print.

[12] Sarker, Sunil.T.S. Eliot: Poetry, Plays and Prose. New Delhi: Atlantic Publishers \& Dist., 2000. Print.

[3] Tiwari, Maneesha. The Plays of T.S. Eliot. New Delhi: Atlantic Publishers \& Dist., 2007. Print.

[14] Vanheste, Jeroen. Guardians of the Humanist Legacy: The Classicism of T.S. Eliot's Criterion Network and Its Relevance to our Postmodern World. The Netherlands: BRILL, 2007. Print. 